University of Nebraska - Lincoln

DigitalCommons@University of Nebraska - Lincoln

Agronomy \& Horticulture - Faculty Publications

Agronomy and Horticulture Department

$1-3-2006$

\title{
Long-Term Effects of Tillage on Soil Chemical Properties and Grain Yields of a Dryland Winter Wheat-Sorghum/Corn-Fallow Rotation in the Great Plains
}

\author{
David D. Tarkalson \\ University of Nebraska-Lincoln, david.tarkalson@ars.usda.gov \\ Gary W. Hergert \\ University of Nebraska-Lincoln, ghergert1@unl.edu \\ Kenneth G. Cassman \\ University of Nebraska-Lincoln, kcassman1@unl.edu
}

Follow this and additional works at: https://digitalcommons.unl.edu/agronomyfacpub

Part of the Plant Sciences Commons

Tarkalson, David D.; Hergert, Gary W.; and Cassman, Kenneth G., "Long-Term Effects of Tillage on Soil Chemical Properties and Grain Yields of a Dryland Winter Wheat-Sorghum/Corn-Fallow Rotation in the Great Plains" (2006). Agronomy \& Horticulture -- Faculty Publications. 95.

https://digitalcommons.unl.edu/agronomyfacpub/95

This Article is brought to you for free and open access by the Agronomy and Horticulture Department at DigitalCommons@University of Nebraska - Lincoln. It has been accepted for inclusion in Agronomy \& Horticulture -Faculty Publications by an authorized administrator of DigitalCommons@University of Nebraska - Lincoln. 


\title{
Long-Term Effects of Tillage on Soil Chemical Properties and Grain Yields of a Dryland Winter Wheat-Sorghum/Corn-Fallow Rotation in the Great Plains
}

\author{
David D. Tarkalson,* Gary W. Hergert, and Kenneth G. Cassman
}

\begin{abstract}
Tillage systems and nutrient management influence soil chemical properties that can impact the long-term sustainability of dryland production systems. This study was conducted to compare the effects of no-till (NT) and conventional till (CT) on the soil chemical properties and grain yield of a dryland winter wheat (Triticum aestivum $\mathbf{L}$.)grain sorghum [Sorghum bicolor (L.) Moench]/corn (Zea mays L.)fallow rotation. The effects of tillage practice over a 27 -yr period (19621989) and the effect of the conversion of CT to NT over a 14-yr period (1989-2003) on selected soil chemical properties [pH, cation exchange capacity (CEC), base saturation (BS), soil organic C (SOC), K, Ca, $\mathrm{Mg}$, and Bray-P] at different soil depths was determined. The acidification rate of the NT treatment from 1962 to 2003 was also determined. The study was conducted at North Platte, NE on a Holdrege silt loam (fine-silty, mixed, mesic Typic Argiustolls). In 1989, there were differences in soil chemical properties between CT and NT at some depths after $27 \mathrm{yr}$. However, in 2003, $14 \mathrm{yr}$ after converting from CT to NT, there were no differences in the soil chemical properties compared with continuous NT. In 1989 and 2003, the soil chemical properties varied with soil depth. The acidification rate from 1962 to 2003 for the NT treatment in the $0-$ to $15-\mathrm{cm}$ depth was $1.3 \mathrm{kmol} \mathrm{H}^{+}$ $\mathrm{ha}^{-1} \mathrm{yr}^{-1}$. This rate of acidification represents $38 \%$ of the total potential acidity from $\mathbf{N}$ fertilizer applications over 41 yr. Acidification was attributed to nitrification of ammonium-based fertilizers and leaching of $\mathrm{NO}_{3}{ }^{-}$. Long-term winter wheat (1966-1983) and grain sorghum (1964-1988) grain yields were higher for NT (2718 and $\left.4125 \mathrm{~kg} \mathrm{ha}^{-1}\right)$ than CT (2421 and $\left.3062 \mathrm{~kg} \mathrm{ha}^{-1}\right)$. Retention of soil moisture as a result of increased residue cover under NT likely contributed to higher NT yields. Soil chemical properties in the wheat-sorghum/corn-fallow rotation will likely continue to change as a result of current management practices. Lime additions may become necessary in the future to ensure the sustainability of crop production in this system.
\end{abstract}

$\mathrm{T}$ HE 2-YR winter wheat-fallow (WF) rotation was the traditional dryland cropping system in the semiarid, central Great Plains in the USA from the time this area was converted to agriculture until the early 1970s. Since then, a 3-yr rotation of winter wheat (Year 1), grain sorghum or corn (Year 2), and fallow (Year 3) (WS/CF) has become a common dryland cropping system (Wicks et al., 1995). Research data showing increased crop yields and profitability of the WS/CF rotation over the WF ro-

D.D. Tarkalson, Dep. of Agron. and Hortic., Univ. of NebraskaLincoln, West Central Res. and Ext. Cent., 461 West University Dr., North Platte, NE 69101; G.W. Hergert, Dep. of Agron. and Hortic., Univ. of Nebraska-Lincoln, Panhandle Res. and Ext. Cent., 4502 Ave. I, Scottsbluff, NE 69361; and K.G. Cassman, Dep. of Agron. and Hortic., Univ. of Nebraska-Lincoln, 387 Plant Science, Lincoln, NE 68583. A contribution of the University of Nebraska Agricultural Research Division, Lincoln, NE 68583. Journal Series no. 14720 Received 10 Sept. 2004. *Corresponding author (dtarkalson2@unl.edu).

Published in Agron. J. 98:26-33 (2006).

Soil Quality and Fertility

doi:10.2134/agronj2004.0240

(C) American Society of Agronomy

677 S. Segoe Rd., Madison, WI 53711 USA tation have facilitated the conversion to the WS/CF rotation (Wicks and Fenster, 1981). This rotation is often called the ecofarming system when it utilizes NT or minimal tillage to conserve soil moisture, which allows more intensive cropping and more stable and higher yields than in the traditional WF rotation (Wicks et al., 1988). Herbicides are applied to winter wheat stubble after grain harvest to keep the field weed free and to conserve soil moisture for grain sorghum or corn that is planted the following spring (Wicks et al., 1995). Some producers still utilize varying degrees of tillage during the fallow period following the row crop to control weeds and facilitate winter wheat planting with conventional drills. The long-term impact of this dryland system, which receives minimal agricultural inputs, on soil properties needs to be assessed. Therefore, it is necessary to assess the differences and changes in soil chemical properties with NT and CT in this rotation.

Studies conducted in semiarid dryland production systems have compared the effects of NT and CT on soil chemical properties. Tillage has been found to decrease SOC compared with NT (Follett and Peterson, 1988). Converting from the traditional WF rotation to more intense cropping systems such as a wheat-corn-fallow (WCF) rotation with NT in the Great Plains can increase SOC in surface soils (Sherrod et al., 2003; Bowman et al., 1999; Wood et al., 1991). The higher SOC under NT was attributed to reducing the amount of tillage and increasing soil water storage, which increases the amount of plant biomass returned to the soil surface. However, in an established WCF rotation in Nebraska, Wicks et al. (1988) found that there were no differences in surface SOC between NT and CT treatments over a 15 -yr period (1964-1979). They also concluded that exchangeable K and $\mathrm{Ca}$ were found to decrease in both CT and NT over time, mostly due to removal in harvested grain. These nutrients were not replenished with fertilizer or lime applications over the life of the study. Research has shown that exchangeable bases decrease in soil not receiving lime as a result of acidification (Bouman et al., 1995). This is often due to removal of exchangeable bases from the exchange sites on clay and organic matter by $\mathrm{H}$ and Al (Singer and Munns, 1999). Differences in acidification between NT and CT can also result in differences in exchangeable bases. There is a need for data on the changes in exchangeable bases due to CT and NT on WS/CF production systems in the Great Plains, which rarely receive lime applications.

The time it takes to detect changes in soil properties

Abbreviations: BS, base saturation; CEC, cation exchange capacity; CT, conventional till; NT, no-till; SOC, soil organic carbon; UAN, urea ammonium nitrate; WCF, wheat-corn-fallow; WF, wheat-fallow; WS/CF, wheat-sorghum/corn-fallow; WSF, wheat-sorghum-fallow. 
after the conversion from CT to NT varies in the literature. While Dick et al. (1991) found little change after only 2 to $3 \mathrm{yr}$ in Ohio, a number of studies have documented significant changes in some chemical properties over longer time periods. For example, significant increases in SOC were reported for the topsoil layer 4 to 28 yr after conversion to NT (Rhoton, 2000; Blevins et al., 1983; Lai et al., 1994; Ismail et al., 1994; Karathanasis and Wells, 1989; Shuman and Hargrove, 1985). The amount of precipitation in a given area will greatly influence the time it takes to notice changes in soil properties.

Soil acidification is generally more pronounced in areas of higher rainfall and on soils with low buffer capacities (Poss et al., 1995). However, the additions of ammonium- and urea-based fertilizers can result in an acceleration soil acidification compared with no fertilization in arid climates with naturally alkaline soils (Bowman and Halvorson, 1998). After 9 yr, Bowman and Halvorson (1998) reported that in Nebraska, $\mathrm{pH}$ values of the surface $5 \mathrm{~cm}$ in a WCF rotation were $6.3,6.2,5.8$, 5.4 , and 5.0 after annual applications of $0,28,56,84$, and $112 \mathrm{~kg} \mathrm{~N} \mathrm{ha}^{-1}$ of either ammonium nitrate or anhydrous ammonia, respectively. The long-term acidification of a calcareous soil under a WC/SF rotation needs to be assessed.

Acidification rates have been reported to range from near 0 to $20 \mathrm{kmol} \mathrm{H} \mathrm{ha}^{-1}$ in research located in a variety of climates and cropping systems (Poss et al., 1995). Factors affecting the acidification of soils include the effects of C, N, S, Mn, Al, and Fe cycles; addition of alkaline materials (e.g., lime); and addition of acids (e.g., acid rain deposition) (Helyar and Porter, 1989; Poss et al., 1995). In most soils, the contribution of the S, Mn, $\mathrm{Al}$, and $\mathrm{Fe}$ cycles to long-term acidification are negligible and are often ignored when determining rates of acidification (Helyar and Porter, 1989). The N cycle plays a large role in the acidification in many agricultural soils, especially when ammonium-based fertilizers are applied (Helyar and Porter, 1989). The acidification of soils receiving ammonium-based fertilizer is driven by nitrification $\left(2 \mathrm{~mol}\right.$ of $\mathrm{H}^{+}$is produced per mole of $\mathrm{NH}_{4}^{+}$) and is influenced by the crop $\mathrm{N}$ fertilizer uptake efficiency. The acidity caused by nitrification can only be neutralized by the release of $\mathrm{OH}^{-}$as $\mathrm{NO}_{3}^{-}$is assimilated by plants (Bouman et al., 1995). Acidification occurs when $\mathrm{NO}_{3}^{-}$is lost due to leaching from the soil zone (Poss et al., 1995). In a study conducted by Poss et al. (1995), the calculated acidification rate of a wheat cropping system in semiarid Australia was between -1.0 and $1.4 \mathrm{kmol} \mathrm{H}^{+} \mathrm{ha}^{-1}$. The acidification was based on the top $25 \mathrm{~cm}$ of soil receiving an annual application of $\mathrm{N}$ as diammonium phosphate and urea at a rate of 157 $\mathrm{kg} \mathrm{N} \mathrm{ha}{ }^{-1}$. They concluded that the near neutral acidification in the root zone was because of small losses of $\mathrm{NO}_{3}^{-}$below the root zone.

Acidification of the soil surface in a WCF rotation has been found to be greater under NT compared with CT (Wicks et al., 1988). Other production systems have come to the same conclusion (Lilienfein et al., 2000; Mahler and Harder, 1984). Differences in acidification of the soil surface in NT and CT systems have been attributed to several factors:

1. Ammonium-based fertilizers are distributed in the soil profile differently (Dick, 1983). In water-limiting environments like the Central Great Plains, it is important to consider the influence of applying greater amounts of $\mathrm{N}$ fertilizer to NT systems compared with CT systems on soil $\mathrm{pH}$ due to the potential for increased productivity from increased water availability as a result of residue cover in NT systems (Halvorson et al., 1999).

2. Differences in grain yield and biomass production can result in varying $\mathrm{C}$ cycle effects. In water-limiting environments, NT has been shown to have higher average crop yields than CT due to the effects of surface residues on soil moisture retention (Bordovsky et al., 1998; Bonfil et al., 1999; Halvorson et al., 2000). The potential differences in production between NT and CT systems can result in greater organic anion exports in grain and accumulation of residue under NT. Differences in residue distribution in the soil profile in the two tillage systems may also influence acidification (Heenan and Taylor, 1995; Lilienfein et al., 2000; Jacobsen and Westerman, 1991).

3. Differences in amount of water leaching through the soil profile. The greater amounts of soil moisture retained under NT may increase $\mathrm{NO}_{3}^{-}$leaching through the soil (Bouman et al., 1995). Although the factors listed above have been used to explain differences in surface soil acidification between NT and CT, the same principles influence acidification of soil at deeper depths.

There is little information on the long-term effects of NT and CT and annual applications of ammoniumbased fertilizers on changes in chemical properties and the acidification rate of soil under the WS/CF rotation. Therefore, our study has four objectives: (i) compare the differences in soil chemical properties after $27 \mathrm{yr}$ of NT and CT (1962-1989), (ii) compare the effects of converting from CT to NT on soil chemical properties over a 14-yr period (1989-2003) in relation to soil under NT for $41 \mathrm{yr}$, (iii) determine the acidification rate of soil under NT from 1962 to 2003, and (iv) determine the influence of tillage treatments on winter wheat, sorghum, and corn grain yields.

\section{MATERIALS AND METHODS}

\section{Experimental Site}

The study was conducted on a Holdrege silt loam (finesilty, mixed, mesic Typic Argiustolls) at the University of Nebraska West Central Research and Extension Center, North Platte, NE. The site was converted from native prairie to a WF rotation under CT in the 1930s. In 1962, a field study was established at the experimental site to assess various weed control strategies in a 3-yr winter wheat-sorghum-fallow (WSF) rotation. This study showed that herbicides could be used to control weeds in NT as effectively as CT (Wicks et al., 1988). The study site consists of three adjacent strips, with each strip containing $1 \mathrm{yr}$ of the 3 -yr rotation (three crop-year 
strips). Grain sorghum was grown in the rotation following winter wheat from 1962 to 1992, and corn was substituted for grain sorghum from 1993 to 2003. Each crop-year strip had five weed management treatments and five replications arranged in a Latin square design. In 1962, the soil had a SOC content of $9.3 \mathrm{~g} \mathrm{~kg}^{-1}$ and a $\mathrm{pH}$ of 7.2 (1:1 soil:water) in the surface $15 \mathrm{~cm}$. A complete description of the original experimental design and treatments are provided by Wicks et al. (1988).

Two of the five weed management treatments from each crop-year strip were used in this study (CT and NT). Tillage for the CT treatment included sweep plowing to a depth of approximately $5 \mathrm{~cm}$ twice after winter wheat harvest and disking to a depth of approximately $10 \mathrm{~cm}$ once in the spring. No herbicides were used in this treatment. The NT treatment used herbicides as the primary weed management strategy and has not been tilled since 1962 . The CT and NT treatments were maintained from 1962 to 1989. In 1989, the CT treatment was converted to NT (called the CT to NT treatment). The original NT weed management regime was maintained continuously in the NT treatments from 1962 to 2003.

Both tillage treatments received identical annual $\mathrm{N}$ fertilizer inputs from 1962 to 1989 before planting wheat and sorghum as ammonium nitrate at an average annual rate of $48 \mathrm{~kg} \mathrm{~N}$ $\mathrm{ha}^{-1}$. From 1990 to 2003, urea ammonium nitrate (UAN) was applied at an average annual rate of $50 \mathrm{~kg} \mathrm{~N}^{-1}$ before planting wheat and corn. A total of $114 \mathrm{~kg} \mathrm{P}^{-1}$ was applied from 1962 to 2003 before planting winter wheat. Fertilizer application rates were based on typical rates adopted by producers using the WS/CF system.

\section{Soil Sampling and Analysis}

Soil samples were taken at depth increments of 0 to 5,5 to 10,10 to 15 , and 15 to $30 \mathrm{~cm}$ in the spring of 1989 and 2003 from all replicate plots of the two tillage treatments in the three crop-year strips. Soil samples were air-dried and ground to pass through a 2-mm sieve before analysis. They were analyzed for $\mathrm{pH}$ (1:1 soil:water), percentage SOC using the Walkley-Black method (Nelson and Sommers, 1982), basic cations extracted by $1 M$ ammonium acetate (Knudsen et al., 1982), CEC using the Ba replacement method (Sumner and Miller, 1996), and Bray-P (Bray and Kurtz, 1945). Base saturation was calculated by dividing the sum of all bases $\left(\mathrm{cmol} \mathrm{kg}{ }^{-1}\right)$ by the CEC $\left(\mathrm{cmol} \mathrm{kg}^{-1}\right.$ ) and then multiplying by 100 (Miller and Gardiner, 2001).

\section{Acidification Rate}

The acidification rate from 1962 to 2003 for the NT treatment was determined for the $0-$ to $15-\mathrm{cm}$ depth. The soil $\mathrm{pH}$ in the surface $15 \mathrm{~cm}$ of the experimental site before implementation of the tillage treatments in 1962 was 7.2 (1:1 soil:water) (Wicks et al., 1988). The acidification rate for the CT treatment was not determined because the bulk density of this treatment was not determined in 1989 when CT was converted to NT (CT to NT). The acidification rate is defined as the rate of $\mathrm{H}$ ion accumulation in a defined soil volume and is estimated by the method of Helyar and Porter (1989) as follows:

$$
\begin{gathered}
\text { Acidification rate }\left(\mathrm{kmol} \mathrm{H}^{+} \mathrm{ha}^{-1} \mathrm{yr}^{-1}\right)= \\
\Delta \mathrm{pH} \times \mathrm{pHBC} \times \mathrm{BD} \times V / \mathrm{TP} / 1000
\end{gathered}
$$

where $\Delta \mathrm{pH}$ is the change in $\mathrm{pH}$ over the time period, $\mathrm{pHBC}$ is the $\mathrm{pH}$ buffer capacity of the soil at the end of the time period $\left(\mathrm{mol} \mathrm{H} \mathrm{H}^{+} \mathrm{kg}^{-1} \mathrm{pH}\right.$ unit $\left.^{-1}\right), \mathrm{BD}$ is the bulk density of the soil $\left(\mathrm{kg} \mathrm{m}^{-3}\right), V$ is the volume of soil per unit area $\left(\mathrm{m}^{3}\right.$ $\mathrm{ha}^{-1}$ ), and TP is the time period (yr).

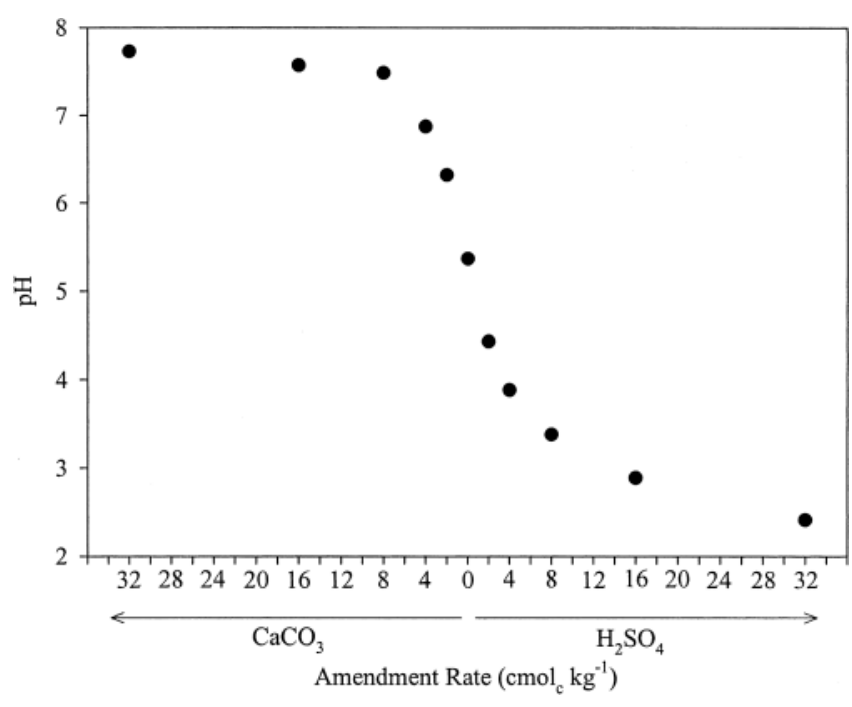

Fig. 1. Titration curve for the no-till treatment. Each point is averaged over depth (0-5, 5-10, and 10-15 cm), four replications, and three crop-year strips.

To determine the $\mathrm{pH}$ buffer capacity of the NT treatment and to check for variability in the $\mathrm{pH}$ buffer capacity across the experimental plots, buffer capacities were determined at each depth for Replications 1 through 4 . The $\mathrm{pH}$ buffer capacities were determined by titrating $50 \mathrm{~g}$ of each soil sample (airdried and passed through a 2-mm sieve) in sealable polyethylene bags with $\mathrm{H}_{2} \mathrm{SO}_{4}$ and $\mathrm{CaCO}_{3}$ applied at rates of $0,2,4,8$, 16 , and $32 \mathrm{cmol}\left(\mathrm{H}^{+}\right.$or $\left.1 / 2 \mathrm{Ca}^{2+}\right) \mathrm{kg}^{-1}$ (Magdoff and Bartlett, 1985). The rates of $\mathrm{CaCO}_{3}$ were added to the soils as a suspension in distilled water. After amendments were added, they were mixed with the soil. Distilled water was added to each treated soil sample to reach field capacity, and then the bags were sealed and stored at room temperature for 1 mo. After $1 \mathrm{mo}$, the treated soil samples were air-dried and ground to pass through a 2-mm sieve for determination of $\mathrm{pH}(1: 1$ soil:water). The buffer capacities varied little between replications and depths. Therefore, $\mathrm{pH}$ readings at each $\mathrm{H}_{2} \mathrm{SO}_{4}$ and $\mathrm{CaCO}_{3}$ rate were averaged over replication and depth to determine the final $\mathrm{pH}$ buffer capacity curve (Fig. 1).

\section{Grain Yields}

At maturity, grain from each tillage treatment within cropyear strips was harvested and removed each year of the study since 1962 although grain yields were not recorded in some years. Crop residues were not removed from the plots.

Grain yields for winter wheat, sorghum, and corn were recorded 26 out of 41,18 out of 30 , and 9 out of $10 \mathrm{yr}$, respectively.

\section{Statistical Analysis Methods}

Analysis of variance was conducted using the Randomized Complete Block Model from Statistix 8 (Analytical Software, 2003). Fifteen replicate plots were used in the statistical analysis of each tillage treatment (five replicate plots for three crop-year strips). Reported values were the means of 15 soil samples. Long-term effects of tillage treatments on soil properties were assessed for the 1962 to 1989 period based on comparison of the soil samples from CT and NT treatments that were taken in 1989. Changes in soil properties due to conversion of CT to NT in relation to the long-term NT treatment were evaluated from the soil samples taken from the CT to NT and NT plots in 2003. Analysis of variance was used to 
Table 1. Effect of tillage treatments on soil chemical properties at depths of 0 to 5,5 to 10,10 to 15 , and 15 to $30 \mathrm{~cm}$ for 1989 and 2003 . Values are the average of five replications of the three crop-year strips (15 replications).

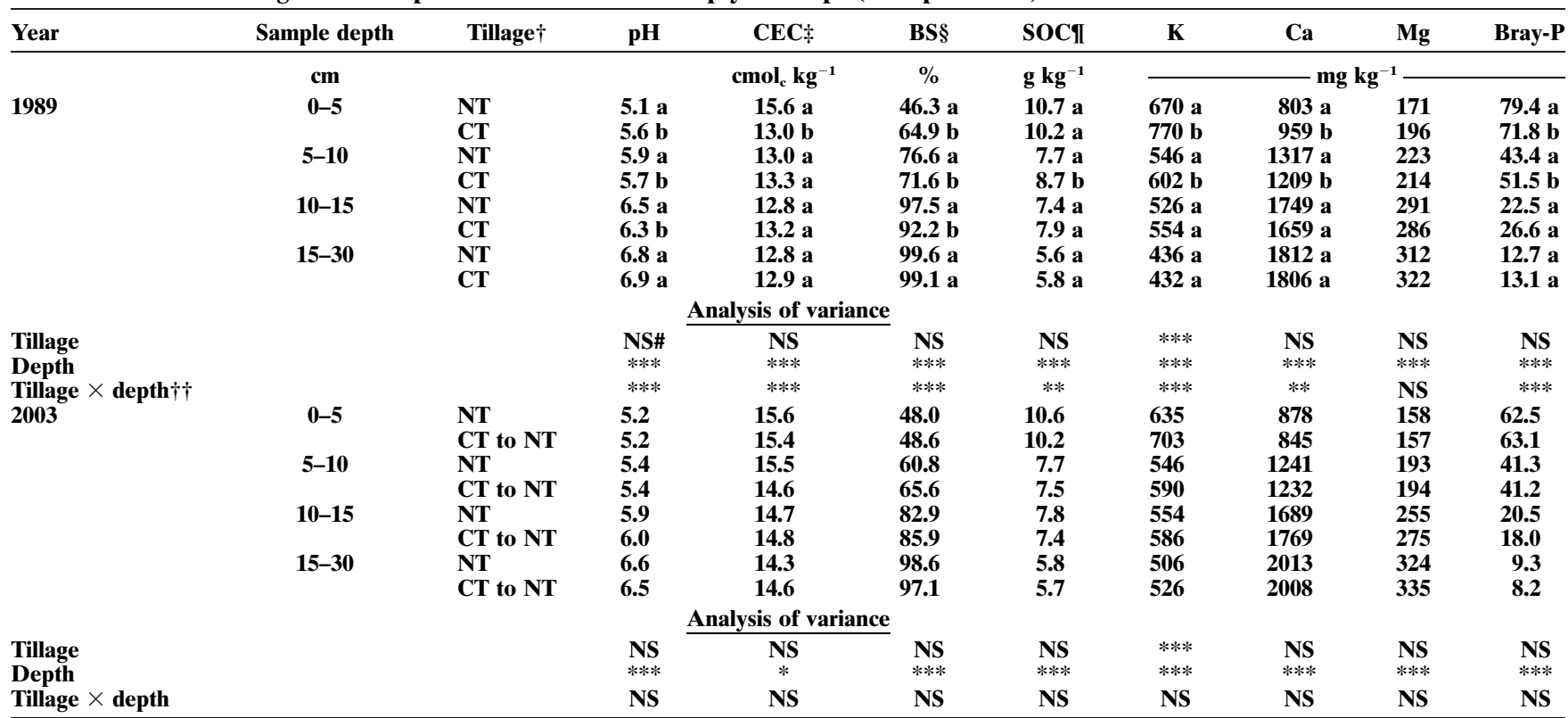

* Significant at the 0.05 probability level.

** Significant at the 0.01 probability level.

$* * *$ Significant at the 0.001 probability level.

$\dagger$ NT, no-tillage; CT, conventional tillage.

+ CEC, cation exchange capacity.

$\S$ BS, base saturation.

II SOC, soil organic carbon.

\# NS, not significant at the 0.05 probability level.

$\dagger \dagger$ Mean separations (LSD) between tillage treatments for each depth were determined for significant tillage $\times$ depth interactions. For each depth, tillage treatments with different letters are significantly different at the 0.05 probability level.

test tillage and soil depth main effects and the tillage $\times$ depth interactions in 1989 and 2003. Least significant difference (LSD) was used to determine the differences between tillage treatment means for each depth in 1989 and 2003 for soil properties with significant tillage $\times$ depth interactions. The soil acidification rate in the NT treatment was estimated from soil samples taken in 2003 and using soil analysis results as recorded in Wicks et al. (1988). Changes in exchangeable bases for the different soil depths in the NT and CT to NT treatments were determined by soil samples taken in 1989 and 2003. Analysis of variance was used to test for differences between years for each tillage treatment and soil depth. Grain yield data were analyzed to determine the effects of tillage treatments on productivity. Analysis of variance was used to test year and tillage main effects and the year $\times$ tillage interactions for winter wheat, sorghum, and corn grain yields. Due to significant year $\times$ tillage interactions, LSD was used to determine the differences between tillage treatment means for each year. Significance was determined for all analysis at the 0.05 probability level.

\section{RESULTS AND DISCUSSION Treatment Effects on Soil Properties from 1962 to 1989}

In 1989, there were differences in soil properties between sampling depths when averaged over tillage practices (Table 1). For both NT and CT, soil pH increased with depth (Table 1). This may be partially attributed to acidification from nitrification of ammonium-based fertilizer in the surface soil layers. Tillage influenced the soil properties at some sampling depths. In 1989, there were no differences in soil properties due to tillage practices when averaged over the 0 - to $30-\mathrm{cm}$ depth except for extractable K. However, there were significant tillage $\times$ depth interactions for $\mathrm{pH}, \mathrm{CEC}, \mathrm{BS}, \mathrm{SOC}$, $\mathrm{K}$, Ca, and Bray-P. Soil $\mathrm{pH}$ was lower for NT (5.1) compared with CT (5.6) in the 0- to 5-cm depth. This can be attributed to the lack of redistribution of higher$\mathrm{pH}$ subsoils and ammonium-based fertilizer deeper in the soil profile from tillage under NT. However, at the 5- to 10-cm depth, the $\mathrm{pH}$ from CT (5.7) was significantly lower than NT (5.9). Redistribution of lower-pH surface soil and ammonium-based fertilizers by tillage into the 5- to $10-\mathrm{cm}$ depth due to tillage was likely the reason for the difference. There were no differences in $\mathrm{pH}$ between NT and CT at depths greater than $10 \mathrm{~cm}$. The $\mathrm{pH}$ for NT and CT averaged 6.4 and 6.9 at the 10- to 15- and 15-to 30-cm depths, respectively. Mahler and Harder (1984) also found differences in soil $\mathrm{pH}$ between NT and CT. Their results reported greatest acidification with NT at the 0- to $7.5-\mathrm{cm}$ depth, whereas for CT it occurred at the $7.5-$ to $15-\mathrm{cm}$ depth. They concluded that the placement of the $\mathrm{N}$ fertilizers under the different tillage systems and subsequent nitrification resulted in these differences.

The significant tillage $\times$ depth interaction for SOC was due to greater SOC in CT at the 5- to 10-cm depth compared with NT (Table 1). This difference was also likely the result of mixing crop residues by tillage in the 
CT treatment. There was no difference in SOC between $\mathrm{CT}$ and NT in the $0-$ to $5-\mathrm{cm}$ depth. This was contrary to past research results, which show significantly higher SOC levels in NT compared with CT (Dick, 1983). However, these results agree with observations by Wicks et al. (1988) on a WCF rotation.

In our study, the NT treatment had a $20 \%$ higher CEC in the 0- to 5-cm depth compared with CT (Table 1). Other research has shown increases in CEC in the surface soils of NT systems compared with CT due to increased SOC (Jaiyeoba, 2003; Ciotta et al., 2003). However, in this study, there were no significant differences in SOC between NT and CT in the soil surface. It is unclear why NT had a higher CEC than CT in the $0-$ to $5-\mathrm{cm}$ depth. A more in-depth investigation is needed to determine the cause of this observation. The 0 - to 5- and 5- to 10-cm layers had less extractable $\mathrm{K}$ and $\mathrm{Ca}$ in NT compared with CT, and although not statistically significant, the 0 - to 5 -cm layer also had less extractable Mg in NT than in CT, and the relative magnitude of differences for these cations was considerably larger than at lower depths. The higher yields and acidification under NT likely resulted in greater removal of these cations in harvested grain and displacement of the cations from the cation exchange sites by $\mathrm{H}$ and $\mathrm{Al}$ over time compared with CT. Base saturation of the NT treatment was reduced compared with the CT at the 0 - to $5-\mathrm{cm}$ depth, which was consistent with the lower extractable bases and $\mathrm{pH}$ in this layer (Table 1).

\section{Treatment Effects on Soil Properties from 1989 to 2003}

The conversion of CT to NT in 1989 produced similar environments in the soils in 2003 as in the treatment with continuous NT since 1962 . For all soil properties measured, there were no significant tillage $\times$ depth interactions in 2003 (Table 1). In 2003, there were still differences in soil properties between sampling depths when averaged over tillage practices, and there were no differences between tillage practices when averaged over the 0 - to $30-\mathrm{cm}$ depth except for the amount of extractable $\mathrm{K}$, which resulted from the CT treatment imposed from 1962 to 1989 (Table 1).

Comparisons between soil properties in 1989 and 2003 show that for both tillage treatments, $\mathrm{pH}$ decreased at all depths, except the 0- to 5-cm depth in the NT treatment, which increased slightly. Soil organic $\mathrm{C}$ did not increase over the 14-yr period in both tillage treatments. This supports the results above, which showed that after $27 \mathrm{yr}$ of NT, SOC was not different than CT. Extractable K and $\mathrm{Ca}$ appear to be leaching through the soil profile in both tillage treatments. In 2003, the extractable $\mathrm{K}$ and Ca were higher in the 15- to 30-cm depth than in 1989 for both tillage treatments (Table 2). In the CT to NT treatment, the extractable $\mathrm{K}, \mathrm{Ca}$, and $\mathrm{Mg}$ are lower in the soil surface in 2003. This is likely a result of crop grain removal and/or leaching. Removal of $\mathrm{P}$ in harvested grain is likely the reason for the decreased concentrations of Bray-P at most sampling depths for both tillage treatments (Table 2). The average decline of Bray-P over all depths was 0.44 and $0.58 \mathrm{mg}$ Bray-extractable $\mathrm{P} \mathrm{kg}^{-1}$ $\mathrm{yr}^{-1}$ for the NT and CT to NT treatments, respectively. During 1989 and 2003, only $30 \mathrm{~kg} \mathrm{P}_{2} \mathrm{O}_{5}$ ha $^{-1}$ was applied to all treatment plots. In both 1989 and 2003, pH, BS, $\mathrm{Ca}$, and $\mathrm{Mg}$ increased with depth while $\mathrm{SOC}, \mathrm{K}$, and Bray P decreased with depth for NT, CT, and CT to NT treatments (Table 1 ).

\section{Acidification Rate}

A titration curve was developed to determine the $\mathrm{pH}$ buffer capacity of the NT treatment in 2003 for the 0 - to 15-cm soil depth (Fig. 1). The soils in this study were highly buffered above $\mathrm{pH} 7$ and below $\mathrm{pH} 4$. Between $\mathrm{pH}$ values of 4 and 7 , the relationship between $\mathrm{pH}$ and $\mathrm{cmol}_{\mathrm{c}}$ addition $\mathrm{kg}^{-1}$ was mostly linear, and therefore, linear regression was used to determine the $\mathrm{pH}$ buffer capacity $\left[\mathrm{mol}_{\mathrm{c}}\left(\mathrm{H}^{+}\right) \mathrm{kg}^{-1}\right.$ unit change in $\left.\mathrm{pH}^{-1}\right]$ of the NT treatment within this $\mathrm{pH}$ range. Based on this linear regression, the $\mathrm{pH}$ buffer capacity was $0.025 \mathrm{~mol} \mathrm{H}^{+}$ $\mathrm{kg}^{-1}$ unit change in $\mathrm{pH}^{-1}$ between $\mathrm{pH}$ values of 4 and $7\left(r^{2}=0.99\right)$. For soil depths 0 to 5,5 to 10 , and 10 to $15 \mathrm{~cm}$, the buffer capacities varied only by a range of $0.004 \mathrm{~mol} \mathrm{H}^{+} \mathrm{kg}^{-1}$ unit change in $\mathrm{pH}^{-1}$ (0.027, 0.025, and $0.023 \mathrm{~mol} \mathrm{H}^{+} \mathrm{kg}^{-1}$ unit change in $\mathrm{pH}^{-1}$, respectively). The acidification rate for NT from 1962 to 2003 in the 0- to $15-\mathrm{cm}$ soil layer was $1.3 \mathrm{kmol} \mathrm{H}^{+} \mathrm{ha}^{-1} \mathrm{yr}^{-1}$. Values for the acidification rate calculation were

$$
\Delta \mathrm{pH}=1.7 \text { [7.2 - 5.5(Table1) }]
$$

$\mathrm{pHBC}\left(\mathrm{mol} \mathrm{H}^{+} \mathrm{kg}^{-1} \mathrm{pH} \mathrm{unit}^{-1}\right)=0.025$

$$
\begin{aligned}
\mathrm{BD}\left(\mathrm{kg} \mathrm{m}^{-3}\right) & =850.9 \\
V\left(\mathrm{~m}^{3} \mathrm{ha}^{-1}\right) & =1500 \\
\mathrm{TP}(\mathrm{yr}) & =41
\end{aligned}
$$

The acidification rate in this study was comparable to calculated acidification rates ranging from -1 to 1.4 $\mathrm{kmol} \mathrm{H}^{+} \mathrm{ha}^{-1} \mathrm{yr}^{-1}$ in the semiarid southeast Australia wheat belt (Poss et al., 1995). The objective of the research by Poss et al. (1995) was to determine the components of the proton budget and the net acidification rate that occur under wheat cultivation in Australia. The approach determines the inputs and outputs of protons $\left(\mathrm{H}^{+}\right)$to and from the soil. The proton budget included effects from the $\mathrm{N}$ cycle, $\mathrm{C}$ cycle, $\mathrm{Mn}$ cycle, $\mathrm{Al}$ cycle, and acid additions. Poss et al. (1995) reported that the major factor in the acidification was loss of $\mathrm{NO}_{3}^{-}$below the root zone. It is possible this may be the case in this study as well, but we did not measure $\mathrm{NO}_{3}^{-}$leaching losses and therefore cannot confirm this finding. However, using a computer model that calculated the daily soil water balance of the WCF rotation over a 10 -yr period (1990-2000), the average percentage of water from precipitation (average $=454 \mathrm{~mm} \mathrm{yr}^{-1}$ ) moving below the $30-\mathrm{cm}$ depth was $35 \%$ (unpublished data, 2005). We do not have the data to calculate the water balance for the entire 41-yr period, but these data show that there was water moving below the $15-\mathrm{cm}$ depth in the experimental plots that can leach $\mathrm{NO}_{3}^{-}$. Also, data showing leaching of basic cations provide support that $\mathrm{NO}_{3}^{-}$not being immobilized or taken up by crops is 
Table 2. Comparison of selected soil properties between 1989 and 2003 for the no-tillage (NT) and conventional tillage (CT) to NT treatments. Analysis of variance is based on 15 replications (five replications from each of the three crop-year strips) for each tillage treatment. Values are presented in Table 1.

\begin{tabular}{|c|c|c|c|c|c|c|c|}
\hline Tillage & Sample depth & pH & $\operatorname{SOC}^{\dagger}+$ & $\mathbf{K}$ & $\mathbf{C a}$ & Mg & Bray-P \\
\hline & cm & & & & & & \\
\hline \multirow[t]{4}{*}{ NT } & $0-5$ & $*$ & NS & NS & NS & NS & $* * *$ \\
\hline & 5-10 & $* * *$ & NS & NS & NS & $* *$ & NS \\
\hline & 10-15 & $* *$ & NS & NS & NS & NS & NS \\
\hline & 15-30 & $* * *$ & NS & $* * *$ & $* * *$ & NS & $* * *$ \\
\hline \multirow{4}{*}{ CT to NT } & $0-5$ & $* * *$ & NS & $*$ & $* * *$ & $* * *$ & $* *$ \\
\hline & $5-10$ & $* * *$ & $* *$ & NS & NS & $* *$ & $* *$ \\
\hline & 10-15 & $*$ & NS & $*$ & NS & NS & $*$ \\
\hline & 15-30 & $* * *$ & NS & $* * *$ & $* *$ & NS & $* * *$ \\
\hline
\end{tabular}

* Significant at the 0.05 probability level.

** Significant at the 0.01 probability level.

$* * *$ Significant at the 0.001 probability level.

$\dagger$ SOC, soil organic carbon.

Table 3. Quantity of ammonium nitrate and urea ammonium nitrate (UAN) applied to each tillage treatment from 1962 to 2003 and their potential acidity and lime equivalent.

\begin{tabular}{|c|c|c|c|c|c|}
\hline \multirow[b]{2}{*}{ N source } & \multicolumn{2}{|c|}{$\mathbf{N}$ applied } & \multirow[b]{2}{*}{ Total } & \multirow{2}{*}{$\begin{array}{l}\text { Potential } \\
\text { acidity } \dagger\end{array}$} & \multirow{2}{*}{$\begin{array}{l}\text { AOAC lime } \\
\text { equivalent }+\end{array}$} \\
\hline & 1962-1989 & 1990-2003 & & & \\
\hline \multirow{4}{*}{$\begin{array}{l}\text { Ammonium nitrate } \\
\text { UAN§ }\end{array}$} & & $\operatorname{kg} \mathbf{N} \mathbf{h a}^{-1}$ & & kmol H' $\mathbf{h a}^{-1}$ & $\mathrm{~kg} \mathrm{CaCO}_{3}$ \\
\hline & 1290 & 0 & 1290 & 92 & 2320 \\
\hline & 23 & 650 & 673 & 48 & 1210 \\
\hline & & & Total $=$ & 140 & 3530 \\
\hline
\end{tabular}

$\uparrow$ Calculated based on the assumption that all fertilizer $\mathrm{N}$ was oxidized to $\mathrm{NO}_{3}^{-}$and 1 mol of $\mathrm{NH}_{4}^{+}$and $\left(\mathrm{NH}_{2}\right)_{2} \mathrm{CO}_{\text {each }}$ results in the production of 2 mol of $\mathrm{H}^{+}$. (Based on total $\mathrm{N}$ applied, $1 \mathrm{~mol}$ of total $\mathrm{N}$ is equal to $1 \mathrm{~mol}$ of $\mathrm{H}^{+}$.)

$\ddagger$ Amount of $\mathrm{CaCO}_{3}\left(\mathrm{CaCO}_{3}\right.$ equivalent $\left.=100 \%\right)$ required to neutralize acidity created by $\mathrm{N}$ fertilizer. [Based on $1.8 \mathrm{~kg} \mathrm{CaCO}$ per $\mathrm{kg} \mathrm{N}$ for ammonium nitrate and UAN (Rasmussen and Rohde, 1989; Spies and Harms, 2004).] $\S \mathbf{3 2} \% \mathbf{N}$.

leaching as well. Further research would help determine the exact causes of the acidification in this soil.

During the course of this study, a total of $1963 \mathrm{~kg} \mathrm{~N}$ $\mathrm{ha}^{-1}$ was applied in all treatment plots since 1962 (Table $3)$. The production of $\mathrm{H}^{+}$from nitrification of $\mathrm{NH}_{4}^{+}$ from ammonium nitrate and urea from UAN is shown in the following reactions (Bouman et al., 1995; Tisdale et al., 1993):

$$
\begin{aligned}
& \mathrm{NH}_{4}^{+}+2 \mathrm{O}_{2} \rightarrow \mathrm{NO}_{3}^{-}+2 \mathrm{H}^{+}+\mathrm{H}_{2} \mathrm{O} \\
& \left(\mathrm{NH}_{2}\right)_{2} \mathrm{CO}+4 \mathrm{O}_{2} \rightarrow 2 \mathrm{NO}_{3}^{-}+2 \mathrm{H}+\mathrm{CO}_{2}+\mathrm{H}_{2} \mathrm{O}
\end{aligned}
$$

Because the $\mathrm{NO}_{3}^{-}$in ammonium nitrate does not produce $\mathrm{H}^{+}$, and assuming that all $\mathrm{N}$ fertilizer was oxidized to $\mathrm{NO}_{3}^{-}$, each kmol of total $\mathrm{N}$ applied is equal to $1 \mathrm{kmol}$ $\mathrm{H}^{+}$. The total amount of potential acidity from total applied $\mathrm{N}$ was equivalent to $140 \mathrm{kmol}$ of $\mathrm{H}^{+} \mathrm{ha}^{-1}$ in the $41 \mathrm{yr}$ since 1962 . In contrast, about $53 \mathrm{kmol} \mathrm{H}^{+} \mathrm{ha}^{-1}$ (1.3 $\mathrm{kmol} \mathrm{H}^{+} \mathrm{ha}^{-1} \mathrm{yr}^{-1} \times 41 \mathrm{yr}$ ) accumulated in the surface $15 \mathrm{~cm}$ of the NT plots during this time (Table 3 ). This amount of soil acidification represents $38 \%$ of the potential acidity that would accrue from the application of $\mathrm{N}$ fertilizer and is equivalent to $724 \mathrm{~kg} \mathrm{~N}^{-1}$ contributing $100 \%$ to soil acidification over the $41 \mathrm{yr}(18.6 \mathrm{~kg}$ $\mathrm{N} \mathrm{ha}{ }^{-1} \mathrm{yr}^{-1}$ ) based on the assumptions listed above. Crop uptake of fertilizer $\mathrm{N}$ was most likely the major reason why not all of the potential acidity from $\mathrm{N}$ fertilizer ended up as accumulated $\mathrm{H}^{+}$. Denitrification was probably less of a factor.

\section{Grain Yields}

No-till increased long-term average winter wheat and grain sorghum yields compared with CT (Table 4). There were significant differences in average winter wheat grain yields from 1966 to 1983 and in average sorghum grain yields from 1964 to 1988 between CT and NT. No-till increased the average winter wheat and sorghum grain yields compared with CT by 300 and $1060 \mathrm{~kg}$ $\mathrm{ha}^{-1}$, respectively. In general, numerous studies have demonstrated that increased crop yields from NT were attributed to greater soil moisture storage due to residue cover in cropping systems in arid and semiarid environments (Bordovsky et al., 1998; Bonfil et al., 1999; Halvorson et al., 2000). After CT treatment plots were converted to NT in 1989, there was a significant residual effect on grain yields of corn and winter wheat in the first year grain yields were measured (Table 5). Thereafter, yields in converted and continuous NT treatments were similar. The winter wheat and corn yields from 1994 to 2003 averaged over tillage were 2880 and $6100 \mathrm{~kg} \mathrm{ha}^{-1}$, respectively. The effects of soil properties on grain yield cannot be clarified due to potential influences of tillage practice on soil moisture storage.

\section{CONCLUSIONS}

Differences in tillage practices (NT and CT) over a 27-yr period resulted in differences in soil chemical properties of a WSF rotation in the Central Great Plains at some depths to $30 \mathrm{~cm}$. However, within $14 \mathrm{yr}$ after converting CT to NT, there were no longer differences in the soil chemical properties compared with long-term NT (41 yr). After 27 yr, NT had lower soil surface pH, extractable $\mathrm{K}$, Ca, and BS compared with NT. However, NT did not increase the SOC levels in the $0-$ to $5-\mathrm{cm}$ soil depth. Increased winter wheat and sorghum grain 
Table 4. Sorghum and winter wheat grain yields from 1964 to 1988 as affected by tillage system. Values are the average of five replications.

\begin{tabular}{|c|c|c|c|c|c|}
\hline \multirow[b]{2}{*}{ Year } & \multicolumn{2}{|c|}{ Sorghum $\dagger$} & \multicolumn{2}{|c|}{ Winter wheat } & \multirow{2}{*}{$\underset{\text { precipitation }}{\text { Annual }}$} \\
\hline & CT & NT & CT & NT & \\
\hline & \multicolumn{4}{|c|}{$\longrightarrow \operatorname{kg~ha}^{-1}$} & $\mathbf{c m}$ \\
\hline 1964 & 3258 a $\div$ & 3648 b & - & - & 47.5 \\
\hline 1965 & 4115 a & 4596 a & - & - & 68.1 \\
\hline 1966 & 3832 a & $4786 a$ & 3062 a & 3013 a & 44.7 \\
\hline 1967 & 2470 a & 3448 b & 3022 a & 2966 a & 44.0 \\
\hline 1968 & 4579 a & 5610 a & 1798 a & 2024 a & 51.4 \\
\hline 1969 & 1012 a & 1543 a & 2160 a & 2514 a & 43.0 \\
\hline 1970 & 2014 a & 3287 b & 1445 a & $1634 \mathrm{~b}$ & 35.4 \\
\hline 1971 & 1616 a & $4796 \mathrm{~b}$ & 1855 a & 2356 a & 58.9 \\
\hline 1972 & 1373 a & 2059 b & 2511 a & 2926 a & 45.8 \\
\hline 1973 & 2693 a & $4623 \mathrm{~b}$ & 2325 a & 2693 a & 54.1 \\
\hline 1974 & 2970 a & 3180 a & 2955 a & 3021 a & 32.5 \\
\hline $1975 \S$ & 966 & 3118 & 2439 a & $2966 \mathrm{~b}$ & 45.3 \\
\hline $1976 \S$ & 192 & 3321 & 1812 a & 2795 b & 44.7 \\
\hline 1977 & 1834 a & 3919 b & 2631 a & 3014 a & $\mathbf{5 7 . 3}$ \\
\hline 1978 & 2875 a & 4592 b & 1430 a & 1689 a & 38.0 \\
\hline 1979 & - & - & 3060 a & 3875 a & $\mathbf{5 7 . 5}$ \\
\hline 1980 & - & - & 2357 a & 2787 a & 41.0 \\
\hline 1981 & 5361 a & $6994 \mathrm{~b}$ & 2843 a & 2773 a & 61.9 \\
\hline 1982 & - & - & 3261 a & 3290 a & 57.8 \\
\hline 1983 & 4358 a & 3674 b & 2608 a & 2584 a & 48.2 \\
\hline 1988 & $4635 a$ & 5248 a & - & - & 51.6 \\
\hline Average & 3062 & 4125 & 2421 & 2718 & \\
\hline \multicolumn{6}{|c|}{ Analysis of variance } \\
\hline Year & \multicolumn{2}{|c|}{ **** } & \multicolumn{2}{|c|}{$* * *$} & \\
\hline Tillage & \multicolumn{2}{|c|}{$* * *$} & \multicolumn{2}{|c|}{$* * *$} & \\
\hline Year $\times$ tillage & \multicolumn{2}{|c|}{$* * *$} & \multicolumn{2}{|c|}{$* *$} & \\
\hline
\end{tabular}

** Significant at the $\boldsymbol{P}=\mathbf{0 . 0 1}$ level.

$* * *$ Significant at the $\boldsymbol{P}=\mathbf{0 . 0 0 1}$ level.

$\dagger$ CT, conventional tillage; NT, no-tillage.

$\downarrow$ Mean separations (LSD) between tillage treatments for each year were determined due to a significant year $\times$ tillage interaction. For each crop and year, tillage treatments with different letters are significantly different at the 0.05 probability level.

$\$$ Plot management error resulted in low sorghum grain yields under CT. These yields were not included in the statistical analysis.

Table 5. Corn and wheat grain yields from 1993 to 2003 as affected by tillage system. Values are the average of five replications.

\begin{tabular}{|c|c|c|c|c|c|}
\hline \multirow[b]{2}{*}{ Year } & \multicolumn{2}{|c|}{ Corn } & \multicolumn{2}{|c|}{ Winter wheat } & \multirow{2}{*}{$\begin{array}{c}\text { Annual } \\
\text { precipitation }\end{array}$} \\
\hline & CT to $\mathbf{N T} \dagger$ & NT & CT to NT & NT & \\
\hline & \multicolumn{4}{|c|}{$-\operatorname{kgha}^{-1}$} & $\mathbf{c m}$ \\
\hline 1993 & 7068 a $\div$ & $7646 \mathrm{~b}$ & - & - & 70.0 \\
\hline 1994 & 8569 a & 8851 a & 2365 a & 2452 b & 43.4 \\
\hline 1995 & $4037 \mathrm{a}$ & $4678 \mathrm{a}$ & 2779 a & 2838 a & 48.7 \\
\hline 1997 & 7841 a & 8486 a & 3236 a & 3364 a & $\mathbf{5 0 . 7}$ \\
\hline 1998 & 8585 a & 7052 b & 3926 a & 3676 a & 51.0 \\
\hline 1999 & $6895 \mathrm{a}$ & $6754 \mathrm{a}$ & 3185 a & 3264 a & 48.2 \\
\hline 2000 & 1668 a & 1807 a & 2091 a & 2136 a & 43.0 \\
\hline 2002 & 7726 a & 7924 a & 2463 a & 2515 a & 23.7 \\
\hline 2003 & 3329 a & 3388 a & 2801 a & 2922 a & 42.9 \\
\hline Average & 6081 & 6117 & 2856 & 2896 & \\
\hline \multicolumn{6}{|c|}{ Analysis of variance } \\
\hline Year & \multicolumn{2}{|c|}{$* \bar{*} *$} & \multicolumn{2}{|c|}{$* * *$} & \\
\hline Tillage & \multirow{2}{*}{\multicolumn{2}{|c|}{$\underset{* * * *}{\mathbf{N S}}$}} & \multicolumn{2}{|c|}{ NS } & \\
\hline Year $\times$ tillage & & & \multicolumn{2}{|c|}{$* * *$} & \\
\hline
\end{tabular}

$* * *$ Significant at the $\boldsymbol{P}=\mathbf{0 . 0 0 1}$ level.

$\dagger$ CT, conventional tillage; NT, no-tillage.

† Mean separations (LSD) between tillage treatments for each year were determined due to a significant year $\times$ tillage interaction. For each crop and year, tillage treatments with different letters are significantly different at the 0.05 probability level.

yields and a higher export of bases in grain were likely the reason for lower exchangeable $\mathrm{K}$ and $\mathrm{Ca}$ in the soil surface under NT. Findings from this study have agreed with past research that has shown lower $\mathrm{pH}$ in the soil surface under NT compared with CT. Differences in the soil $\mathrm{pH}$ between NT and CT after $27 \mathrm{yr}$ were likely due to the redistribution of soil and $\mathrm{N}$ fertilizers with tillage. The $\mathrm{WC} / \mathrm{SF}$ rotation under NT acidified at a rate of $1.3 \mathrm{kmol} \mathrm{H}^{+} \mathrm{ha}^{-1} \mathrm{yr}^{-1}$ in the surface $15 \mathrm{~cm}$ from 1962 to 2003 . In this system, only $38 \%$ of the potential acidity from the total applied $\mathrm{N}$ was realized. The applications of ammonium-based fertilizers and subsequent nitrification and leaching of $\mathrm{NO}_{3}^{-}$may have been the primary cause of acidification in this soil. The apparent movement of soil water below the sampling depth and the leaching of bases in this soil over time provide evidence that $\mathrm{NO}_{3}^{-}$leaching may have contributed to the acidification of the NT system. It appears that if management practices remain the same, the soil will continue to slowly acidify. Low $\mathrm{pH}$ in the soil surface may lead to the inactivation of certain herbicides resulting in a need to apply lime. At this rate of acidification, lime applications to prevent $\mathrm{Al}$ and $\mathrm{Mn}$ toxicity may be needed in the future on this soil.

No-till in this cropping system increased long-term grain yield averages for winter wheat and grain sorghum compared with CT. Sorghum grain yields increased under NT compared with CT to a greater extent than winter wheat. This study was not able to differentiate between the influences of soil moisture status and changes in soil chemical properties on grain yield under CT and NT. Therefore, more research is needed to determine the role of changing soil chemical properties over time on crop yields.

\section{REFERENCES}

Analytical Software. 2003. Statistix 8. Analytical Software, Tallahassee, FL.

Blevins, R.L., G.W. Thomas, M.S. Smith, W.W. Frye, and P.L. Cornelius. 1983. Changes in soil properties after 10 years continuous nontilled and conventionally tilled corn. Soil Tillage Res. 3:135-146.

Bonfil, D.J., I. Mufradi, S. Klitman, and S. Asido. 1999. Wheat grain yield and soil profile water distribution in a no-till arid environment. Agron. J. 91:368-373.

Bordovsky, D.G., M. Choudhary, and C.J. Gerard. 1998. Tillage effects on grain sorghum and wheat yields in the Texas rolling plains. Agron. J. 90:638-643.

Bouman, O.T., D. Curtin, C.A. Campbell, V.O. Biederbeck, and H. Ukainetz. 1995. Soil acidification from long-term use of anhydrous ammonia and urea. Soil Sci. Soc. Am. J. 59:1488-1494.

Bowman, R.A., and A.D. Halvorson. 1998. Soil chemical changes after nine years of differential $\mathrm{N}$ fertilization in a no-till dryland wheat-corn-fallow rotation. Soil Sci. 163:241-247.

Bowman, R.A., M.F. Vigil, D.C. Nielsen, and R.L. Anderson. 1999. Soil organic matter changes in intensively cropped dryland systems. Soil Sci. Soc. Am. J. 63:186-191.

Bray, R.H., and L.T. Kurtz. 1945. Determination of total organic and available forms of phosphorus in soils. Soil Sci. Soc. Am. J. 59:39-45.

Ciotta, M.N., C. Bayer, S.M.V. Fontoura, P.R. Ernani, and J.A. Albuquerque. 2003. Soil organic matter and cation exchange capacity increases in a low activity clay soil under no-tillage system. Cienc. Rural 33:1161-1164.

Dick, W.A. 1983. Organic carbon, nitrogen, and phosphorus concentrations and $\mathrm{pH}$ in soil profiles as affected by tillage intensity. Soil Sci. Soc. Am. J. 47:102-107.

Dick, W.A., E.L. McCoy, W.M. Edwards, and R. Lai. 1991. Continuous application of no-tillage to Ohio soils. Agron. J. 83:65-73.

Follett, R.F., and G.A. Peterson. 1988. Surface soil nutrient distribution as affected by wheat-fallow tillage systems. Soil Sci. Soc. Am. J. 52:141-147.

Halvorson, A.D., A.L. Black, J.M. Krupinsky, S.D. Merrill, B.J. Wienhold, and D.L. Tanaka. 2000. Spring wheat response to tillage and 
nitrogen fertilization in rotation with sunflower and winter wheat. Agron. J. 92:136-144.

Halvorson, A.D., C.A. Reule, and R.F. Follett. 1999. Nitrogen fertilization effects on soil carbon and nitrogen in a dryland cropping system. Soil Sci. Soc. Am. J. 63:912-917.

Heenan, D.P., and A.C. Taylor. 1995. Soil pH decline in relation to rotation, tillage, stubble retention and nitrogen fertilizer in S.E. Australia. Soil Use Manage. 11:4-9.

Helyar, K.R., and W.M. Porter. 1989. Soil acidification, its measurement and the process involved. p. 61-102. In A.D. Robson (ed.) Soil acidity and plant growth. Academic Press, Sydney.

Ismail, I., R.L. Blevins, and W.W. Frye. 1994. Long-term no-tillage effects on soil properties and continuous corn yields. Soil Sci. Soc. Am. J. 58:193-198.

Jacobsen, J.S., and R.L. Westerman. 1991. Stratification of soil acidity derived from nitrogen fertilization in winter wheat tillage systems. Commun. Soil Sci. Plant Anal. 22:1335-1346.

Jaiyeoba, I.A. 2003. Changes in soil properties due to continuous cultivation in Nigerian semiarid Savannah. Soil Tillage Res. 70: 91-98.

Karathanasis, A.D., and K.L. Wells. 1989. A comparison of mineral weathering trends between two management systems on a catena of loess-derived soils. Soil Sci. Soc. Am. J. 53:582-588.

Knudsen, D., G.A. Petersen, and P.F. Pratt. 1982. Lithium, sodium, and potassium. p. 225-246. In A.L. Page et al. (ed.) Methods of soil analysis. Part 2. 2nd ed. Agron. Monogr. 9. ASA, Madison, WI.

Lai, R., A.A. Mahboubi, and N.R. Fausey. 1994. Long-term tillage and rotation effects on properties of a central Ohio soil. Soil Sci. Soc. Am. J. 59:517-522.

Lilienfein, J., W. Wilcke, L. Vilela, S.D. Lima, R. Thomas, and W. Zech. 2000. Effect of no-till and conventional tillage systems on the chemical composition of soils solid phase and soil solution of Brazilian savanna oxisols. J. Plant Nutr. Soil Sci. 163:411-419.

Magdoff, F.R., and R.J. Bartlett. 1985. Soil pH buffering revisited. Soil Sci. Soc. Am. J. 49:145-148.

Mahler, R.L., and R.W. Harder. 1984. The influence of tillage methods, cropping sequence, and $\mathrm{N}$ rates on the acidification of a northern Idaho soil. Soil Sci. 137:52-60.

Miller, R.W., and D.T. Gardiner. 2001. Soils in our environment. 9th ed. Prentice Hall, Upper Saddle River, NJ.
Nelson, D.W., and L.E. Sommers. 1982. Total carbon, organic carbon, and organic matter. p. 539-579. In A.L. Page et al. (ed.) Methods of soil analysis. Part 2. 2nd ed. Agron. Monogr. 9. ASA, Madison, WI.

Poss, R., C.J. Smith, F.X. Dunin, and J.F. Angus. 1995. Rate of soil acidification under wheat in a semi-arid environment. Plant Soil 177:85-100.

Rasmussen, P.E., and C.R. Rohde. 1989. Soil acidification from ammonium-nitrogen fertilization in moldboard plow and stubble-mulch wheat-fallow tillage. Soil Sci. Soc. Am. J. 53:119-122.

Rhoton, F.E. 2000. Influence of time on soil response to no-till practices. Soil Sci. Soc. Am. J. 64:700-709.

Sherrod, L.A., G.A. Petersen, D.G. Westfall, and L.R. Ahuja. 2003. Cropping intensity enhances soil organic carbon and nitrogen in a no-till agroecosystem. Soil Sci. Soc. Am. J. 67:1533-1543.

Shuman, L.M., and W.L. Hargrove. 1985. Effect of tillage on the distribution of manganese, copper, iron, and zinc in soil fractions. Soil Sci. Soc. Am. J. 49:1117-1121.

Singer, M.J., and D.N. Munns. 1999. Soils: An introduction. 4th ed. Macmillian Publ. Co., Upper Saddle River, NJ.

Spies, C.D., and C.L. Harms. 2004. Soil acidity and liming of Indiana soils [Online]. Available at www.agry.purdue.edu/ext/forages/ publications/ay267.htm (verified 17 Aug. 2005). Purdue Univ., West Lafayette, IN.

Sumner, M.E., and W.P. Miller. 1996. Cation exchange capacity, and exchange coefficients. p. 1201-1229. In D.L. Sparks et al. (ed.) Methods of soil analysis. Part 3: Chemical properties. 3rd ed. ASA and SSSA, Madison, WI.

Tisdale, S.L., W.L. Nelson, J.D. Beaton, and J.L. Havlin. 1993. Soil fertility and fertilizers. Macmillan Publ., New York.

Wicks, G.A., and C.R. Fenster. 1981. Ecofarming fallow aids in winter wheat fallow rotation. NebGuide G81-546-A. Univ. of Nebraska, Lincoln

Wicks, G.A., D.E. Smika, and G.W. Hergert. 1988. Long-term effects of no-tillage in a winter wheat (Triticum aestivum)-sorghum (Sorghum bicolor)-fallow rotation. Weed Sci. 36:384-393.

Wicks, G.A., P.W. Stahlman, and R.L. Anderson. 1995. Weed management systems for semiarid areas of the central Great Plains. Proc. North Cent. Weed Sci. Soc. 50:174-190.

Wood, C.W., D.G. Westfall, and G.A. Petersen. 1991. Soil carbon and nitrogen changes on initiation of no-till cropping systems. Soil Sci. Soc. Am. J. 55:470-476. 